\title{
Soybean response to NPK fertilization of sowing and potassium at topdressing in soil of improved fertility
}

Clério Hickmann ${ }^{1}$

Álvaro Vilela de Resende ${ }^{2}$

Carlos Alberto Silva 3

Julian Junio de Jesus Lacerda 4

Antonio Eduardo Furtini Neto 5

Silvino Guimarães Moreira ${ }^{6}$

\section{Abstract}

The introduction of indeterminate habit soybean cultivars expanded the possibilities of rotation or succession crops in producing areas of the Cerrado region, but it represents a less well-known component in the management of soil fertility. The objective of this work was to verify the agronomic and economic response of indeterminate habit soybean to the variations in NPK fertilization of sowing and potassium at topdressing in an improved fertility Latosol in Campos das Vertentes (MG). The experimental design was in randomized blocks, with subdivided plots in three replications. In plots, the treatments consisted of doses of 315 and $485 \mathrm{~kg} \mathrm{ha}^{-1}$ of NPK 02-30-10 formulation in the sowing furrow and, in the subplots, the application of $0,15,30$ and $45 \mathrm{~kg} \mathrm{ha}^{-1}$ of $\mathrm{K}_{2} \mathrm{O}$ in topdressing at 21 days after sowing was tested. There is no significant difference in the variation of sowing fertilization, but grain yield increases linearly by the additional input of potassium at topdressing. Soybean cultivar requires more $\mathrm{K}_{2} \mathrm{O}$ in maintenance fertilization in soil of improved fertility to express productive potential near $4 \mathrm{t} \mathrm{ha}^{-1}$, which is economically rewarding.

Keywords: Potassium fertilization. Indeterminate habit soybean. High investment agriculture.

\section{Introduction}

Continuous fertilizations and residual effect of potassium fertilizers on clay soils resulted in good availability of potassium (K) in crops under long-term cultivation in no-tillage system (NTS) (FOLONI; ROSOLEM, 2008; RESENDE, 2011).

In soils with nutrient contents above critical levels, additional increments in maintenance fertilization are not expected to result in gain yield that are economically rewarding. However, the definition of $\mathrm{K}$ content corresponding to the critical level seems to depend on local conditions. According

1 Universidade do Oeste de Santa Catarina (UNOESC) - Departamento de Agronomia, professor. São Miguel do Oeste, Santa Catarina, Brasil. clerioh@gmail.com. Rua Oiapoc, 211, Bairro Agostini, São Miguel do Oeste (SC). CEP 89900-000.

2 Empresa Brasileira de Pesquisa Agropecuária - Embrapa Milho e Sorgo/CNPMS, pesquisador. Sete Lagoas, Minas Gerais, Brasil. alvaro. resende@embrapa.br. Rodovia MG 424, Km 65-Zona Rural, Caixa postal 151, Sete Lagoas (MG), CEP 35701-970.

3 Universidade Federal de Lavras (UFLA) - Departamento de Ciência do Solo, professor. Lavras, Minas Gerais, Brasil. csilva@dcs.ufla.br. Campus Universitário, Caixa Postal 3037, Lavras (MG). CEP 37200-000.

4 Universidade Federal de Piaú́ (UFPI) - Departamento de Agronomia, professor. Bom Jesus, Piaui, Brasil. julianlacerda@gmail.br. Rodovia Bom Jesus-Viana km 01, Bom Jesus (PI). CEP 64900-000.

5 Universidade Federal de Lavras (UFLA) - Departamento de Ciência do Solo, professor. Lavras, Minas Gerais, Brasil. afurtini@dcs.ufls. br. Campus Universitário, Caixa Postal 3037, Lavras (MG). CEP 37200-000.

6 Universidade Federal de Lavras (UFLA) - Departamento de Ciência do Solo, professor. Lavras, Minas Gerais, Brasil. silvino@ufsj.edu. br. Campus Universitário, Caixa Postal 3037, Lavras (MG). CEP 37200-000. 
to Alvarez V. et al. (1999), the critical level of $\mathrm{K}$ for soils of Minas Gerais is $70 \mathrm{mg} \mathrm{dm}^{-3}$, while Vilela et al. (2004) consider the range of 50 to $80 \mathrm{mg} \mathrm{dm}^{-3}$ as suitable for clay soils of the Cerrado region. In the southern region of Brazil, a new critical level of $\mathrm{K}$ was established for soybean crop under no-tillage (SOCIEDADE BRASILEIRA DE CIÊNCIA DO SOLO, 2004; BRUNETTO et al., 2005). It was found that the critical level previously established at $80 \mathrm{mg} \mathrm{dm}^{-3}$ should be upgraded to $60 \mathrm{mg} \mathrm{dm}^{-3}$, as soybean did not respond to fertilization in soils with availability above this value. For soils originating from basalt grown under no-tillage and crop rotation in Parana, Oliveira Júnior et al. (2010) and Empresa Brasileira de Pesquisa Agropecuária (EMBRAPA, 2011) do not recommend applying potassium fertilization in soybean for initial availability of $\mathrm{K}$ in soil greater than $117 \mathrm{mg} \mathrm{dm}^{-3}$, since the critical content for the crop is $78 \mathrm{mg} \mathrm{dm}^{-3}$.

In Minas Gerais state, the official recommendations of NPK fertilizers for soybean (NOVAIS, 1999) were established for conventional planting systems. For a K availability between 71 and $120 \mathrm{mg} \mathrm{dm}^{-3}$ and expected yield of up to $3 \mathrm{t} \mathrm{ha}^{-1}$, the recommendation would be $40 \mathrm{~kg} \mathrm{ha}^{-1} \mathrm{~K}_{2} \mathrm{O}$. A question to be answered is whether this statement is still valid for production areas that adopt high technological level related to the management of fertility and increasingly use of productive potential cultivars in NTS.

The Campos das Vertentes mesoregion has been consolidating as a major grain producer, and soybean is being used as a crop rotation option in the NTS. The use of early cultivars of indeterminate habit (the plant presents at the beginning of the flowering only between 50 and $60 \%$ of its final height and the flowering begins at the 4th or 5th node of the main stem and progresses down and up on the plant stem) is presented as a promising strategy, including to enable other crops in the second harvest. These genotypes have a number of agronomic advantages, especially the anticipation of sowing time, precocity, high harvest rate, upright growth and small leaflets, which facilitates the management of insect pests and diseases, and flexibility of plants spatial arrangements (OLIVEIRA JÚNIOR et al., 2013; PROCÓPIO et al., 2013).

Although there are reports of very productive crops, little is known about the nutritional requirements of this new type of cultivar (BORGES et al., 2013). This study aimed to verify whether the indeterminate habit soybean responds agronomic and economically to changes in NPK fertilizer of sowing and potassium at topdressing on soil of improved fertility, under NTS in Campos das Vertentes region (MG).

\section{Material and methods}

The experiment was conducted between October 2011 and March 2012 at Santa Helena Farm, located at $21^{\circ} 15^{\prime} 40^{\prime \prime}$ south latitude and 4430'30" west longitude, located in Nazareno (MG), a municipality belonging to the region of Campos das Vertentes. The altitude of the place is $1,020 \mathrm{~m}$. The soil was classified as a dystrophic Red Latosol with clay texture (EMBRAPA, 2006), and it has a management history with high technological investment for grain production. The area was managed without soil preparation by eight seasons of corn crop, remaining in fallow with spontaneous vegetation in the off-season. In this period, only in one year, the off-season crop was used, the sunflower.

The soybean crop Nidera IN 5909 RR, of indeterminate habit, was sown with use of mechanical traction seeder (with nine sowing lines spaced $0.6 \mathrm{~m}$ ) in maize rotation on October 21 , 2011 , with estimated final population of 380 thousand plants ha-1. The experimental design was randomized blocks, with subdivided plots, in three replicates. The plots consisted of nine spaced 
rows of $0.6 \mathrm{~m}$ and $40 \mathrm{~m}$ in length. Here, the applications of 315 and $485 \mathrm{~kg} \mathrm{ha}^{-1}$ of the formulated NPK 02-30-10 (32 and $49 \mathrm{~kg} \mathrm{ha}^{-1}$ of $\mathrm{K}_{2} \mathrm{O}$ ) were compared, distributed in the sowing furrow of 5 $\mathrm{cm}$ deep. The lowest dose corresponded to the fertilization normally employed on the farm, and the highest dose aimed to enable possible responses of soybean to the increment in sowing fertilization, and is about $50 \%$ above the $315 \mathrm{~kg} \mathrm{ha}^{-1}$ dose of the formulated NPK 02-30-10 applied on the farm in soybean sowing. In the subplots, with $10 \mathrm{~m}$ in length, treatments with $0,15,30$ and $45 \mathrm{~kg} \mathrm{ha}^{-1}$ of $\mathrm{K}_{2} \mathrm{O}$ in the form of potassium chloride $(\mathrm{KCl})$ were compared. The doses were manually applied in continuous strip between the lines, at stage V2, 21 days after sowing (DAS). The cultural treatments were applied, according to technical recommendations of the manufacturers and suppliers, the herbicides glyphosate and paraguat dichloride, for desiccation and control of weeds; the insecticides flubendiamide, chlorpyrifos, lufenuron and thiamethoxam + lambda-cyhalothrin, for the control of bedbugs, caterpillars and mites; and fungicides trifloxystrobin + prothioconazole and trifloxystrobin + cyproconazole, for fungi control. Seeds were inoculated with Azospitillum brasiliensis, in amount of $229 \mathrm{~mL} 60$ thousand seeds ${ }^{-1}$ ( $1 \mathrm{~mL}=5$ billion bacteria).

For the treatment of seeds, the insecticide fipronil was used to protect seedlings against seed pest action. Boron micronutrients were also applied, $2 \mathrm{~kg}^{-1}$ of sodium octaborate in mixture with NPK fertilizer was applied in sowing, cobalt and molybdenum, via foliar, using $96 \mathrm{~mL} \mathrm{ha}^{-1}$ of the nutritional compound Quimifol CoMo Plus, which constituted 1\% of cobalt and $6 \%$ of molybdenum in the form of chelated cobalt sulfate and sodium molybdate.

Before the application of potassium at topdressing treatments, a soil sampling in soybean lines was performed to characterize the general conditions of fertility in the experimental area (Table 1 ). The availability of $\mathrm{K}$ above the critical levels (70 to $80 \mathrm{mg} \mathrm{dm}^{-3}$ ) established for the nutrient is remarkable (ALVAREZ V. et al., 1999; VILELA et al., 2004). At the full flowering and at the end of the crop cycle, other soil samples were taken in the subplots, collecting nine simple samples, three in the lines of sowing and six in the lines of the soybean. At flowering, leaf sampling was also made, composed of 15 trifoliate leaves per subplot, removing the third or fourth fully expanded trifoliate from the plant apex. Soil and vegetable tissue analyzes were performed according to methods specified by Silva (2009).

Table 1. Chemical and physical characterization of the experimental area soil, at depth of 0 to $20 \mathrm{~cm}$, before fertilization with potassium.

\begin{tabular}{|c|c|c|c|c|c|c|c|c|c|c|c|c|c|}
\hline $\mathrm{pH}_{\text {water }}$ & $P *$ & $\mathrm{~K}^{*}$ & $\mathrm{~s}$ & $\mathrm{Zn}$ & $\mathrm{Fe}$ & $\mathrm{Mn}$ & $\mathrm{Cu}$ & P-rem & V & $\mathrm{Ca}$ & $\mathrm{Mg}$ & $\mathrm{H}+\mathrm{Al}$ & $\mathbf{T}$ \\
\hline & & \multicolumn{5}{|c|}{ - } & & $\mathrm{mg} \mathrm{L}^{-1}$ & $\%$ & \multicolumn{4}{|c|}{ 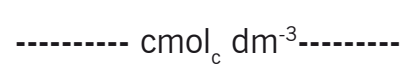 } \\
\hline 5.7 & 8 & 103 & 34 & 5 & 38 & 16 & 2 & 5 & 36 & 2.3 & 0.6 & 5.5 & 8.8 \\
\hline \multicolumn{4}{|c|}{ Sand } & \multicolumn{4}{|c|}{ Silt } & \multicolumn{2}{|c|}{ Clay } & \multicolumn{4}{|c|}{ Organic Matter } \\
\hline \multicolumn{14}{|c|}{ 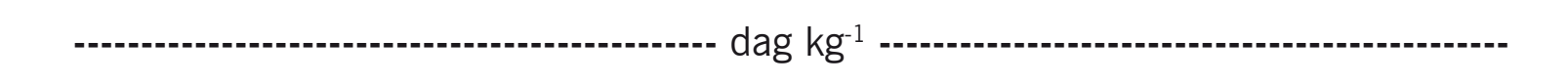 } \\
\hline \multicolumn{4}{|c|}{17} & \multicolumn{4}{|c|}{25} & \multicolumn{2}{|c|}{58} & \multicolumn{4}{|c|}{4.9} \\
\hline
\end{tabular}

*Extractor: Mehlich-1.

Source: Elaborated by the authors (2017) 
At 131 DAS, three rows of soybean plants with $4 \mathrm{~m}$ length each were harvested in the central area of the subplots. After mechanical threshing, the grain yield was determined by adjusting their moisture content to $130 \mathrm{~g} \mathrm{~kg}^{-1}$. From the quantification of nutrient contents in the grains, according to Silva (2009), the export of $\mathrm{K}$ by soybean was estimated considering the nutrient content in the grains multiplied by the total dry mass of grains.

Data were submitted to analysis of variance. The means of fertilization treatments at sowing were compared by the $F$ test, and regression models were adjusted for the dependent variables in relation to the $\mathrm{K}_{2} \mathrm{O}$ doses applied at topdressing. The statistical program Sisvar (FERREIRA, 2011) was used.

An economic analysis was made based on the costs of fertilizers and $\mathrm{KCl}$ application at top dressing, faced with the revenue generated from the sale of the grains. Fertilization treatment yield was calculated in relation to the standard management of the farm (application of $315 \mathrm{~kg} \mathrm{ha}^{-1}$ of NPK 02-30-10 at sowing, without potassium applied at top dressing).

\section{Results and discussion}

There was no significant effect of NPK fertilization on sowing and its interaction with potassium applied at top dressing in the studied variables. However, it was observed a significant influence of $\mathrm{K}$ application at top dressing in the levels of $\mathrm{K}$ in the soil at the time of flowering and after harvest, on soybean yield and $\mathrm{K}$ exported (Table 2 ).

Table 2. Summary of the analysis of variance for $K$ contents in soil, leaves, and grains, total $K$ exported and soybean yield in relation to NPK fertilization at sowing and potassium applied at topdressing.

\begin{tabular}{|c|c|c|c|c|c|c|c|}
\hline \multirow{3}{*}{$\begin{array}{l}\text { Source of } \\
\text { variation }\end{array}$} & \multicolumn{7}{|c|}{ Mean Square } \\
\hline & \multicolumn{3}{|c|}{$\mathrm{K}_{\text {Mehlich-1 }}$ in soil } & \multirow{2}{*}{ K-leaf } & \multirow{2}{*}{ K-grain } & \multirow{2}{*}{ K-exported } & \multirow{2}{*}{ Grain yield } \\
\hline & GL & Flowering & $\begin{array}{l}\text { End of } \\
\text { cycle }\end{array}$ & & & & \\
\hline Block & 2 & $409^{n s}$ & $269^{\text {ns }}$ & $0.059^{\text {ns }}$ & $0.134^{\mathrm{ns}}$ & $98.65^{\mathrm{ns}}$ & $223026^{\text {ns }}$ \\
\hline NPK sowing (S) & 1 & $26^{\text {ns }}$ & $1097^{n s}$ & $0.032^{\mathrm{ns}}$ & $1.307^{\mathrm{ns}}$ & $20.70^{\text {ns }}$ & $203320^{\text {ns }}$ \\
\hline Error 1 & 2 & 359 & 351 & 0.031 & 1.382 & 42.45 & 67628 \\
\hline $\mathrm{K}$ topdressin(C) & 3 & $1522^{*}$ & $1291^{*}$ & $0.018^{\text {ns }}$ & $1.247^{\mathrm{ns}}$ & 178.99* & $444911^{*}$ \\
\hline $\mathrm{S} \times \mathrm{C}$ & 3 & $167^{\mathrm{ns}}$ & $134^{\mathrm{ns}}$ & $0.026^{\mathrm{ns}}$ & $0.036^{\mathrm{ns}}$ & $2.09^{n s}$ & $5328^{\text {ns }}$ \\
\hline Error 2 & 12 & 312 & 251 & 0.041 & 0.653 & 44.69 & 95303 \\
\hline Total & 23 & & & & & & \\
\hline CV $1(\%)$ & & 19.9 & 20.6 & 6.9 & 6.0 & 9.0 & 7.0 \\
\hline CV $2(\%)$ & & 18.6 & 17.4 & 8.0 & 4.1 & 9.2 & 8.4 \\
\hline
\end{tabular}


Although the quantities supplied at topdressing were relatively small, there was a linear increase in $\mathrm{K}$ availability in soil evaluated at the time of flowering; this effect was also observed in the sampling performed after the soybean harvest (Figure 1).

Figure 1. Soil $K$ contents in the flowering phase and after harvest, on the basis of NPK rates in sowing fertilization ( $\mathrm{A}$ and $\mathrm{C}$ ) and $\mathrm{K}_{2} \mathrm{O}$ at topdressing $(\mathrm{B}$ and $\mathrm{D})$ in soybean crop
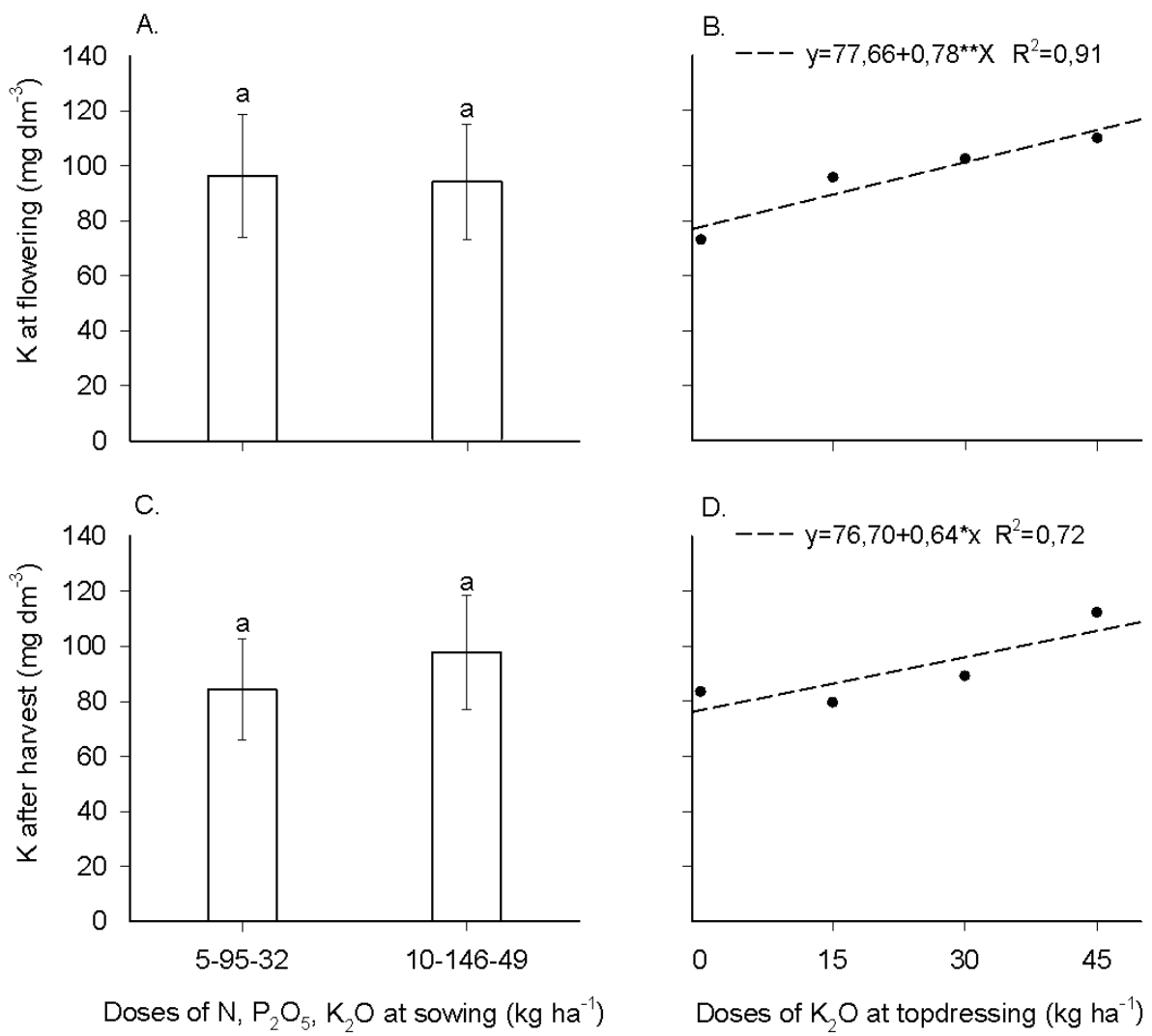

*,** Significant at $5 \%$ and $1 \%$ probability level, respectively, by the $\mathrm{F}$ test.

Source: Elaborated by the authors (2017)

The content of $103 \mathrm{mg} \mathrm{dm}^{-3}$ of $\mathrm{K}$ at the beginning of soybean cycle can be considered relatively high, which, coupled with the availability of other nutrients (Table 1), features a soil of improving fertility condition. Additionally, it was expected that the buffering of this soil constituted of $58 \mathrm{dag} \mathrm{kg}^{-1}$ of clay would be enough to guarantee the productive potential expression of soybean, even under lower levels of fertilization. This buffering seems to have confirmed, in part, by the lack of response to variation in sowing NPK fertilizer, where there was differential contribution of these nutrients, especially phosphorus. However, data in Figure 1 show that the higher dose of the top dressing fertilization with $\mathrm{K}$ was necessary to maintain the initial nutrient level in soil until the end of soybean cycle, confirming that $\mathrm{K}$ reserve available in the studied Latosol can fall relatively quickly (OLIVEIRA JÚNIOR et al., 2013).

In the absence of potassium applied at top dressing, there was a reduction in the availability of about $20 \mathrm{mg} \mathrm{dm}^{-3}$, placing it close to $80 \mathrm{mg} \mathrm{dm}^{-3}$, but still remaining in the range considered adequate by Alvarez V et al. (1999) and Vilela et al. (2004). To restore the amount of K exported by soybean it is necessary to provide $20 \mathrm{~kg}$ of $\mathrm{K}_{2} \mathrm{O}$ per ton of grains harvested (EMBRAPA, 2011; OLIVEIRA JUNIOR et al., 2013).

In the treatments combinations, absolute grain yield ranged from 3.3 to $4.1 \mathrm{t} \mathrm{ha}^{-1}$, which represents export values between 66 and $82 \mathrm{~kg} \mathrm{ha}^{-1}$ of $\mathrm{K}_{2} \mathrm{O}$, while the quantities supplied were between 
31 and $93 \mathrm{~kg} \mathrm{ha}^{-1}$ of $\mathrm{K}_{2} \mathrm{O}$. Thus, the yields (Figure 2) and soil nutrient contents (Figure 1 ), increasing with the doses of potassium applied at top dressing, confirm that this fertilization was important to complement the amount applied at sowing.

Figure 2. Grain yield and quantity of $K$ exported on the basis of NPK levels in sowing fertilization ( $A$ and $C$ ) and $\mathrm{K}_{2} \mathrm{O}$ in topdressing ( $\mathrm{B}$ and $\mathrm{D}$ ) in soybean crop
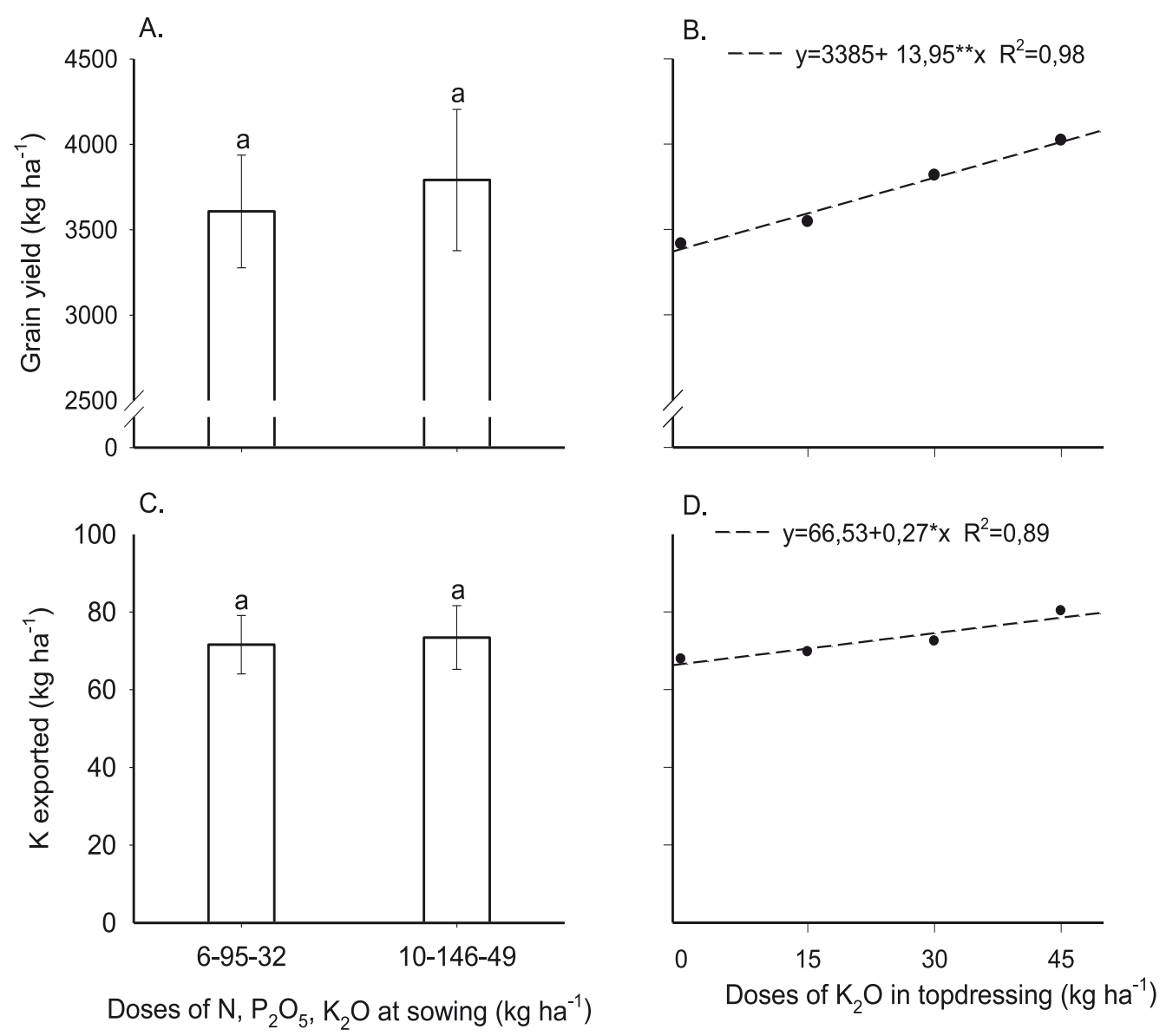

*.** Significant at $5 \%$ and $1 \%$ probability level, respectively, by the $\mathrm{F}$ test.

Source: Elaborated by the authors (2017).

As the topdressing fertilization was increased, $\mathrm{K}$ was accessible to the plants at the beginning of the crop more intense absorption phase, leading to yield gains (LANA et al., 2002). The highest nutrient contributions were effective in guaranteeing the accumulation in the grains for higher yields, without soil fertility depletion (Figure 1 ).

Soy extracts about $38 \mathrm{~kg}$ of $\mathrm{K}_{2} \mathrm{O}$ per ton of grains produced, and export is $53 \%$ of what is absorbed during the cycle (EMBRAPA, 2011). Therefore, there may be soil fertility impairment for crop in succession when maintenance fertilization is performed in suboptimal doses. Wendling et al. (2008) indicate that, for soils with high $\mathrm{K}$ availability (up to twice the critical content), maintenance fertilization should be performed to restore the amount exported plus any losses of the nutrient in the system. According to the authors, the recommendation is that a quantity of $25 \%$ above the export be applied.

The present work showed the high productive potential of a modern genotype of soybean, which reached abnormal levels compared to the pattern observed until some years ago in Minas Gerais state. The yields reached and the corresponding $\mathrm{K}$ export were higher than the modal values of the crop at the time of the definition of the recommendations of Novais (1999) for soybean fertilization in the state of Minas Gerais. 
According to Novais (1999), the application of $40 \mathrm{~kg}^{-1}$ of $\mathrm{K}_{2} \mathrm{O}$ would be sufficient to produce up to $3 \mathrm{t} \mathrm{ha}^{-1}$ of grains in soils of improved fertility. In the new reality presented, with grain yield close to $4 \mathrm{t} \mathrm{ha}^{-1}$, the maintenance of high productive potential environments requires greater attention not only to replace $\mathrm{K}$ exported in harvests, but to preserve the nutrient content in soil in levels consistent with crops intensity in the rotation system.

This argument is supported by the balance of $\mathrm{K}$ in production systems established by Oliveira Junior et al. (2010) based on the recommendations for the cultivation of soybean in soils of improved fertility in the states of Paraná, São Paulo and Cerrado region. The suggested doses for a productivity expectation of $3 \mathrm{t} \mathrm{ha}^{-1}$ in these regions are 50 to $60 \mathrm{~kg} \mathrm{ha}^{-1}$ of $\mathrm{K}_{2} \mathrm{O}$, from which the authors found that there is a risk of a negative balance, that is, a deficit in nutrient stocks in soils, to the detriment of crops which are components of the production systems. In fact, the obtainment of maximum yields ranging from 3.3 to $4.1 \mathrm{t} \mathrm{ha}^{-1}$ in Latosols in São Paulo state (FOLONI; ROSOLEM, 2008) and Piauí state (PETTER et al., 2012) was associated with providing doses between 85 and $97 \mathrm{~kg} \mathrm{ha}^{-1}$ of $\mathrm{K}_{2} \mathrm{O}$.

It is important to point out that, despite the response to the top dressing fertilization obtained in the present study, the total amount of $\mathrm{K}$ supplied is more interesting than the application season. Options to apply $\mathrm{K}$ at different seasons, before or after soybean sowing, have already had their demonstrated effectiveness (FOLONI; ROSOLEM, 2008; PETTER et al, 2012, 2014). In order to avoid problems of the fertilizer saline effect on soybean germination, the application in the sowing furrow should be limited to $60 \mathrm{~kg} \mathrm{ha}^{-1}$ of $\mathrm{K}_{2} \mathrm{O}$ (VILELA et al., 2004; OLIVEIRA JUNIOR et al., 2010) and the remainder of the maintenance dose delivered in pre-sowing or in top dressing.

$\mathrm{K}$ contents in leaves at flowering time and in grains remained relatively constant between treatments (Table 3). This can be explained by the continued productivity gains with increases in nutrient supply, so that increases absorption were promptly mobilized to meet the physiological demand for increasing grain production (Lana et al., 2002), the concentrations present in each organ of the plant being stable.

Table 3. Levels of $\mathrm{K}\left(\mathrm{g} \mathrm{kg}^{-1}\right)$ in soybean leaves and grains, based on NPK doses in sowing fertilization and on $\mathrm{K}_{2} \mathrm{O}$ in topdressing.

\begin{tabular}{|c|c|c|c|c|c|c|c|}
\hline \multicolumn{3}{|c|}{$\begin{array}{l}\text { Sowing Fertilization }{ }^{1} \\
\left(\mathrm{~kg} \mathrm{ha}^{-1}\right)\end{array}$} & \multicolumn{4}{|c|}{$\begin{array}{l}\text { Topdressing Fertilization }{ }^{2} \\
\left(\mathrm{~kg} \mathrm{ha}^{-1}\right)\end{array}$} & \multirow[t]{2}{*}{ Mean } \\
\hline $\mathbf{N}$ & $\mathrm{P}_{2} \mathrm{O}_{5}$ & $\mathrm{~K}_{2} \mathrm{O}$ & 0 & 15 & 30 & 45 & \\
\hline & & & \multicolumn{5}{|c|}{ K-leaf } \\
\hline 6 & 95 & 32 & 25.7 & 24.8 & 25.2 & 24.3 & 25.0 \\
\hline 10 & 146 & 49 & 25.2 & 24.5 & 26.8 & 26.4 & 25.7 \\
\hline \multirow[t]{2}{*}{ Mean } & & & 25.5 & 24.7 & 26.0 & 25.3 & 25.4 \\
\hline & & & \multicolumn{5}{|c|}{ K-grain } \\
\hline 6 & 95 & 32 & 20.0 & 19.9 & 19.2 & 20.3 & 19.8 \\
\hline 10 & 146 & 49 & 19.7 & 19.3 & 18.7 & 19.7 & 19.3 \\
\hline Mean & & & 19.8 & 19.6 & 18.9 & 20.0 & 19.5 \\
\hline
\end{tabular}

1,2 Significant effect at $5 \%$ probability level by the $\mathrm{F}$ test. Non-significant interaction among the sources of variation at $5 \%$ probability level.

Source: Elaborated by the authors (2017)

The foliar contents ranged from 24 to $27 \mathrm{~g} \mathrm{~kg}^{-1}$, classified in the ranges of interpretation considered appropriate for different producing regions of the country (EMBRAPA, 2011) above the refe- 
rence value or critical level proposed for the crop in Minas Gerais (MARTINEZ et al., 1999). Santos et al. (2008) and Oliveira et al. (2013) point out the need for higher K-foliar contents in soybeans to obtain high yields in Cerrado clay soils and indeterminate habit cultivars. Therefore, there was no luxury consumption, and since a maximum point in the response curve was not reached (Figure 2), it is possible that the crop used presented even higher yields if it received higher doses of K. Other studies show there are soil and fertilization management conditions that promote luxury consumption, it can result in higher export taxes of the nutrient (FOLONI; ROSOLEM, 2008 PETTER et al, 2012.).

$\mathrm{K}$ concentrations in grains varied slightly between the treatments (Table 3 ), causing the exported quantities to be directly related to productivity, reaching about $80 \mathrm{~kg} \mathrm{ha}^{-1}$ of $\mathrm{K}_{2} \mathrm{O}$ (Figure 2). This shows that higher yield levels have a strong impact on the dynamics of $\mathrm{K}$ in the soil-plant system; it reinforces the need for the farmer constantly monitor the fertility status of the cultivation environment.

In the experimental conditions of this work, the soil analysis allowed to detect variations in the availability of $\mathrm{K}$ associated to the grain yield differences, which was not possible with the foliar analysis.

There was no significant difference in productivity between soybean plants that received NPK fertilizer normally used by the farm at sowing or the increased dose (Figure 2).

On the other hand, the additional supply of $\mathrm{K}$ during the cycle provided an absolute gain of up to $756 \mathrm{~kg} \mathrm{ha}^{-1}$ of grains, starting from the worst scenario (application of only $33 \mathrm{~kg} \mathrm{ha}^{-1}$ at sowing) for the best ( $48+45 \mathrm{~kg} \mathrm{ha}^{-1}$ of $\mathrm{K}_{2} \mathrm{O}$ in sowing + top dressing).

The economic analysis confirmed that there was no advantage in increasing NPK fertilizer at sowing, but higher yields were obtained as the potassium input increased (Table 4).

Table 4. Profitability due to treatments of NPK fertilization in sowing and potassium applied at topdressing in soybean.

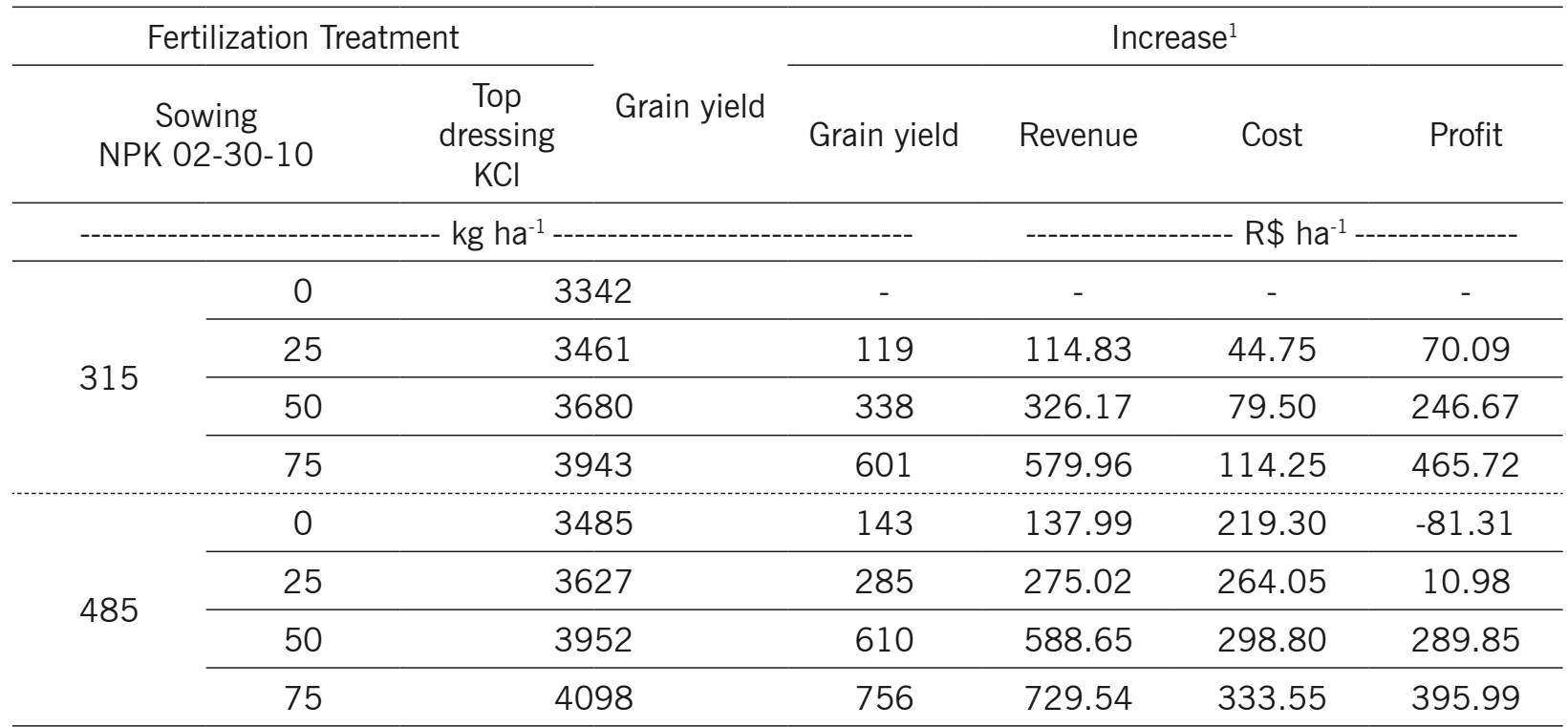

${ }^{1}$ Increases observed in relation to the farm standard management (application of $315 \mathrm{~kg} \mathrm{ha}^{-1}$ of NPK 02-3010 , without potassium applied at top dressing). Price per kg of fertilizer: NPK 02-30-10 = R $\$ 1.29 ; \mathrm{KCl}=\mathrm{R} \$$ 1.39. Cost of the mechanized application of $\mathrm{KCl}$ at topdressing: $\mathrm{R} \$ 10.00$ per hectare. Value of the $60 \mathrm{~kg}$ bag of soybean $\mathrm{R} \$ 57.92$. US dollar value on October $9,2014=\mathrm{R} \$ 2.388$.

Source: Elaborated by the authors (2017)

The economic feasibility of the investment in potassium fertilization in the conditions of the studied soil was verified, however, with the linear response to the nutrient, it was not possible to identify the maximum return dose. 
In a general analysis of the results obtained, it is understood that the cultivar of soybean of indeterminate habit allowed reaching high yield levels in soils with improved fertility in the region of Campos das Vertentes (MG), but it requires a higher K supply. Thus, soil availability levels considered adequate in the literature (ALVAREZ V. et al., 1999; VILELA et al., 2004) may not be compatible or the recommended maintenance doses (NOVAIS 1999; SOUSA; LOBATO, 2004) may not be sufficient to guarantee the demand of these more productive crops.

The situation observed in Campos das Vertentes diverges even from the most recent recommendations regarding the management of soils associated with Cerrado vegetation (SOUSA; LOBATO, 2004). These authors suggest that, for an initial $\mathrm{K}$ availability above $80 \mathrm{mg} \mathrm{dm}^{-3}$, the application of 40 to $50 \mathrm{~kg} \mathrm{ha}^{-1}$ of $\mathrm{K}_{2} \mathrm{O}$ would make it possible to produce between 3 and $4 \mathrm{t} \mathrm{ha}^{-1}$ of soybean. This expectation was not confirmed in the present study, at which only with the total dose of $93 \mathrm{~kg} \mathrm{ha}^{-1}$ of $\mathrm{K}_{2} \mathrm{O}$ (48 $\mathrm{kg}$ at sowing and $45 \mathrm{~kg}$ at top dressing) it was possible to reach $4 \mathrm{t} \mathrm{ha}^{-1}$ of harvested grains and restore export preserving the initial $\mathrm{K}$ level available in soil. Therefore, there is an indication of the need for further experimentation to define new nutritional demand indices and critical levels in soil and plant.

\section{Conclusions}

Soybean yield increases linearly with the addition of potassium fertilization at topdressing and does not vary in the addition of potassium at sowing.

$\mathrm{K}$ contents in leaves and grains do not vary by the additional contribution of potassium fertilization and total $\mathrm{K}$ export is proportional to the grain yield.

Indeterminate habit soil crop requires more $\mathrm{K}$ in maintenance fertilization in soil of improved fertility under a no-tillage system, which is economically rewarding.

\section{Acknowledgements}

To FAPEMIG, for the financial support and scholarships. To CNPq, for the scholarship. To Santa Helena Farm, for the experimental area. To Embrapa Maize and Sorghum, for the aid in field, laboratory and for financing part of the study actions.

\section{Resposta da soja à adubação NPK de semeadura e cobertura potássica em solo de fertilidade construída}

\section{Resumo}

A introdução de cultivares de soja de hábito indeterminado ampliou as possibilidades de cultivos em rotação ou sucessão em áreas produtoras da região do Cerrado, mas representa um componente menos conhecido no manejo da fertilidade do solo. O objetivo deste trabalho foi verificar a resposta agronômica e econômica da soja de hábito indeterminado a variações na adubação NPK de semeadura e cobertura potássica num Latossolo Vermelho de fertilidade construída nos Campos das Vertentes (MG). O delineamento experimental foi em blocos casualizados, com parcelas subdivididas, em três repetições. Nas parcelas os tratamentos consistiram de doses de 315 e $485 \mathrm{~kg} \mathrm{ha}^{-1}$ do formulado NPK 02-30-10 no sulco de semeadura, e nas subparcelas testou-se a aplicação de 0, 15, 30 e $45 \mathrm{~kg} \mathrm{ha}^{-1}$ de $\mathrm{K}_{2} \mathrm{O}$ em cobertura aos 21 dias após a semeadura. Não há diferença significativa na 
variação da adubação de semeadura, mas a produtividade aumenta linearmente pelo aporte adicional de potássio em cobertura. A cultivar de soja requer mais $\mathrm{K}_{2} \mathrm{O}$ na adubação de manutenção em solo de fertilidade construída para expressar potencial produtivo próximo de 4 t ha-1 ${ }^{-1}$ o que é economicamente compensador.

Palavras-chave: Adubação potássica. Soja de hábito indeterminado. Agricultura de alto investimento.

\section{Referências}

ALVAREZ V. V. H.; NOVAIS, R. D.; BARROS, N. D.; CANTARUTTI, R. B.; LOPES, A. S.; RIBEIRO, A. C. Interpretação dos resultados das análises de solos. In: RIBEIRO, A. C.; GUIMARÃES, P. T. G.; ALVAREZ V. V. H. (eds.). Comissão de fertilidade do solo do Estado de Minas Gerais. "Recomendações para o uso de corretivos e fertilizantes em Minas Gerais. Viçosa: Comissão de Fertilidade do Solo do Estado de Minas Gerais, v. 5, p. 25-32. 1999.

BORGES, W. L. B.; MATEUS, G. P.; FREITAS, R. S.; LAZARINI, E.; CAZENTINI FILHO, G.; HIPÓLITO, J. L.; TOKUDA, F. S.; TOMAZINI, N. R.; GASPARINO, A. C.; FINOTO, E. L. Avaliação regional de cultivares de soja no noroeste paulista - safras 2011/12 e 2012/13. Nucleus - Revista Científica da Fundação Educacional de Ituverava, Ituverava, v. 10, n. 3, p. 23-42, Ed. especial, 2013. Disponível em: <http://www.nucleus.feituverava.com.br/index.php/nucleus/article/view/915/1079>. Acesso em: 20 maio 2016.

BRUNETTO, G.; GATIBONI, L. C.; SANTOS, D. R. dos; SAGGIN, A.; KAMINSKI, J. Nível crítico e resposta das culturas ao potássio em um Argissolo sob sistema plantio direto. Revista Brasileira de Ciência do Solo, Viçosa, v. 29, p. 569-571, jul./ago. 2005. Disponível em: <http://www.scielo.br/ pdf/\%0D/rbcs/v29n4/26105.pdf>. Acesso em: 20 maio 2016.

EMPRESA BRASILEIRA DE PESQUISA AGROPECUÁRIA - EMBRAPA. Centro Nacional de Pesquisa de Solos. Sistema brasileiro de classificação de solos. Brasília: Embrapa Produção de Informação. Rio de Janeiro: Embrapa Solos, 2006. 312p.

EMPRESA BRASILEIRA DE PESQUISA AGROPECUÁRIA - EMBRAPA. Tecnologias de produção de soja: região central do Brasil 2012 e 2013. Londrina: Embrapa Soja, 2011. 261p. Disponível em: <http://www.cnpso.embrapa.br/download/SP15-VE.pdf>. Acesso em: 20 maio 2016.

FERREIRA, D. F. Sisvar: a computer statistical analysis system. Ciência e Agrotecnologia, Lavras, v. 35, n. 6, p. 1039-1042, nov./dez. 2011. Disponível em: <http://www.scielo.br/pdf/cagro/v35n6/ a01v35n6.pdf>. Acesso em: 20 maio 2016.

FOLONI, J. S. S. ; ROSOLEM, C. A. Produtividade e acúmulo de potássio na soja em função da antecipação da adubação potássica no sistema plantio direto. Revista Brasileira de Ciência do Solo, Viçosa, v. 32, p. 1549-1561, 2008. Disponível em: <http://repositorio.unesp.br/bitstream/handle/11449/5829/ S0100-06832008000400019.pdf?sequence $=1$ \&isAllowed $=y>$. Acesso em: 20 maio 2016.

LANA, R. M. Q.; HAMAWAKI, O. T.; LIMA, L. M. L. de; ZANÃO JUNIOR, L. A. Resposta da soja a doses e modos de aplicação de potássio em solo de cerrado. Bioscience Journal, v. 18. p. 17 23, dez. 2002. Disponível em: <http://www.seer.ufu.br/index.php/biosciencejournal/article/viewArticle/6415>. Acesso em: 20 maio 2016. 
MARTINEZ, H. E. P.; CARVAlHO, J. de; SOUZA, R. de, RIBEIRO, A. C.; GUIMARÃES, P. T. G. Diagnose foliar. In: RIBEIRO, A. C.; GUIMARÃES, P. T. G.; ALVAREZ V. V. H. (eds.). Recomendações para o uso de corretivos e fertilizantes em Minas Gerais: $5^{\mathrm{a}}$ aproximação. Viçosa: Comissão de Fertilidade do Solo do Estado de Minas Gerais, 1999.

NOVAIS, R. F. Soja. In: RIBEIRO, A. C.; GUIMARÃES, P. T. G.; ALVAREZ V. V. H. (eds.). Recomendações para o uso de corretivos e fertilizantes em Minas Gerais: $5^{a}$ aproximação. Viçosa: Comissão de Fertilidade do Solo do Estado de Minas Gerais, 1999.

OLIVEIRA JUNIOR, A.; CASTRO, C.; KLEPKER, D.; OLIVEIRA, F. A. Soja. In: PROCHNOW, L. I.; CASARIN, V.; STIP, S. R. (eds.). Boas práticas para o uso eficiente de fertilizantes: culturas. Piracicaba: IPNI, 2010. v. 3, p. 1-38.

OLIVEIRA JUNIOR, A.; CASTRO, C. de; OLIVEIRA, F. A. de; JORDAO, L. T. Adubação potássica da soja: cuidados no balanço de nutrientes. Informações Agronômicas, Piracicaba, n. 143, set., p. 1-10. Disponível em: <http://www.ipni.net/publication/ia-brasil.nsf/0/272AC1ADEF76D54B83257BF80046D30F/\$FILE/Page1-10-143.pdf>. Acesso em: 20 maio 2016.

PETTER, F. A.; Silva, J. A. da; AlCANTARA NetO, F.; PACHECO, L. P.; ALMEIDA, F. A. de; SANTOS, G. G.; LIMA, L. B. de. Productivity and yield components of soybeans under dose and potassium application period in Piauí savannah. Journal of Agricultural Science, v. 4, p. 173-171, 2012. Disponível em: <http://search.proquest.com/openview/02eff93185d36795b76fccdd69300c3b/1?pq-origsite $=$ gscholar $>$. Acesso em: 20 maio 2016.

PetTer, F. A.; AlVeS, A. U.; SIlVA, J. A. da; AlMEIDA, E. C.; AliXANDRE, T. F.; AlMEIDA, F. A.; PACHECO, L. P. Produtividade e qualidade de sementes de soja em função de doses e épocas de aplicação de potássio no cerrado piauiense. Semina: Ciências Agrárias, Londrina, v. 35, p. 89-100, jan./fev. 2014. Disponível em: <http://www.uel.br/revistas/wrevojs246/index.php/semagrarias/article/view/11656>. Acesso em: 20 maio 2016.

PROCÓPIO, S. O.; BALBINOT JÚNIOR, A. A.; DEBIASI, H.; FRANCHINI, J. C.; PANISON, F. Plantio cruzado na cultura da soja utilizando uma cultivar de hábito de crescimento indeterminado. Revista de Ciências Agrárias, v. 56, n. 4, p. 319-325, out./dez. 2013. Disponível em: <https://periodicos.ufra.edu.br/index.php?journal=ajaes\&page =article\&op =view\&path\%5B\%5D =1135\&path\%5B\%5D=412>. Acesso em: 20 maio 2016.

RESENDE, A. V. de. 0 sistema plantio direto proporciona maior eficiência no uso de fertilizantes. Sete Lagoas: Embrapa Milho e Sorgo, 2011. Disponível em: <http://ainfo.cnptia.embrapa.br/digital/ bitstream/item/51390/1/doc-118.pdf>. Acesso em: 20 maio 2016.

SANTOS, F. C. dos; NOVAIS, R. F.; NEVES, J. C. L.; FOLONI, J. M.; ALBUQUERQUE FILHO, M. R. de; KER, J. C. Produtividade e aspectos nutricionais de plantas de soja cultivadas em solos de cerrado com diferentes texturas. Revista Brasileira de Ciência do Solo, Viçosa, v. 32, p. 2015-2025, 2008. Disponível em: <http://www.scielo.br/pdf/rbcs/v32n5/23.pdf>. Acesso em: 20 maio 2016.

SILVA, F. C. (Ed.). Manual de análises químicas de solos, plantas e fertilizantes. Brasília: Embrapa Informações Tecnológicas, 2009. 627p. 
SOCIEDADE BRASILEIRA DE CIÊNCIA DO SOLO. COMISSÃO DE QUÍMICA E FERTILIDADE DO SOLO - CQFSRS/SC. Manual de adubação e calagem para os Estados do Rio Grande do Sul e de Santa Catarina. 10. ed. Porto Alegre: Comissão Química e Fertilidade do Solo, 2004. 404p.

SOUSA, D. M. G.; LOBATO, E. Calagem e adubação para culturas anuais e semiperenes. In: (eds.). Cerrado: correção do solo e adubação. 2. ed. Planaltina: Embrapa, 2004. cap. 12, p. 283-315.

VILELA, L.; SOUSA, D. M. G.; SILVA, J. E. Adubação com potássio. In: SOUSA, D. M. G.; LOBATO, E. (eds.). Cerrado: correção do solo e adubação. 2. ed. Planaltina: Embrapa, 2004. cap. 6, p. 147-168.

WENDLING, A.; ELTZ, F. L. F.; CUBILLA, M. M.; AMADO, T. J. C.; MIELNICZUK, J. Recomendação de adubação potássica para trigo, milho e soja sob sistema plantio direto no Paraguai. Revista Brasileira de Ciência do Solo, Viçosa, v. 32, n. 5, p. 1929-1939, set./out. 2008. Disponível em: <http://www.lume.ufrgs.br/bitstream/handle/10183/79915/000693479. pdf? sequence $=1>$. Acesso em: 20 maio 2016.

\section{Histórico editorial:}

Submetido em: 26/01/2016

Aceito em: 25/05/2016

How to cite this article:

$\underline{A B N T}$

HICKMANN, C.; RESENDE, A. V. de; SILVA, C. A.; LACERDA, J. J. J.; FURTINI NETO, A. E.; MOREIRA, S. G. Soybean response to NPK fertilization of sowing and potassium at topdressing in soil of improved fertility. Revista Agrogeoambiental, Pouso Alegre, v. 9, n. 2, p. 37-48, abr./jun. 2017. Doi: http://dx.doi.org/10.18406/2316-1817v9n22017942

$\underline{\text { APA }}$

HICKMANN, C., RESENDE, A. V. de, SILVA, C. A., LACERDA, J. J. J., FURTINI NETO, A. E. \& MOREIRA, S. G. (2017). Soybean response to NPK fertilization of sowing and potassium at topdressing in soil of improved fertility. Revista Agrogeoambiental, Pouso Alegre, 9 (2), 37-48. Doi: http://dx.doi.org/10.18406/2316-1817v9n22017942

ISO

HICKMANN, C.; RESENDE, A. V. de; SILVA, C. A.; LACERDA, J. J. J.; FURTINI NETO, A. E. e MOREIRA, S. G. Soybean response to NPK fertilization of sowing and potassium at topdressing in soil of improved fertility. Revista Agrogeoambiental, 2017, vol. 9, n. 2, pp. 37-48. Eissn 2316-1817. Doi: http://dx.doi.org/10.18406/2316-1817v9n22017942

\section{VANCOUVER}

Hickmann C, Resende AV, Silva CA, Lacerda JJJ, Furtini Neto AE, Moreira SG. Soybean response to NPK fertilization of sowing and potassium at topdressing in soil of improved fertility. Rev agrogeoambiental. 2017 abr/jun; 9(2): 37-48. Doi: http://dx.doi.org/10.18406/2316-1817v9n22017942 